\title{
Correction: Comparing the genomes of Helicobacter pylori clinical strain UM032 and mice-adapted derivatives
}

Yalda Khosravi ${ }^{1}$, Vellaya Rehvathy ${ }^{1}$, Wei Yee Wee ${ }^{2}$, Susana Wang ${ }^{3}$, Primo Baybayan ${ }^{3}$, Siddarth Singh ${ }^{4}$, Meredith Ashby ${ }^{3}$, Junxian Ong ${ }^{5}$, Arlaine Anne Amoyo ${ }^{5}$, Shih Wee Seow ${ }^{5}$, Siew Woh Choo ${ }^{2}$, Tim Perkins ${ }^{6}$, Eng Guan Chua ${ }^{7}$, Alfred Tay ${ }^{7}$, Barry James Marshall ${ }^{7}$, Mun Fai Loke ${ }^{1}$, Khean Lee Goh ${ }^{8}$, Sven Pettersson ${ }^{5,9,10}$ and Jamuna Vadivelu ${ }^{1 *}$

\section{Correction}

After publication of this work [1], we discovered that due to an inadvertent mistake, Figures 4 and 5 in the original article were essentially the same figure. Amendment to Figure 5 (Figure 1 here) has now been added. We offer our sincerest apologies for this oversight.
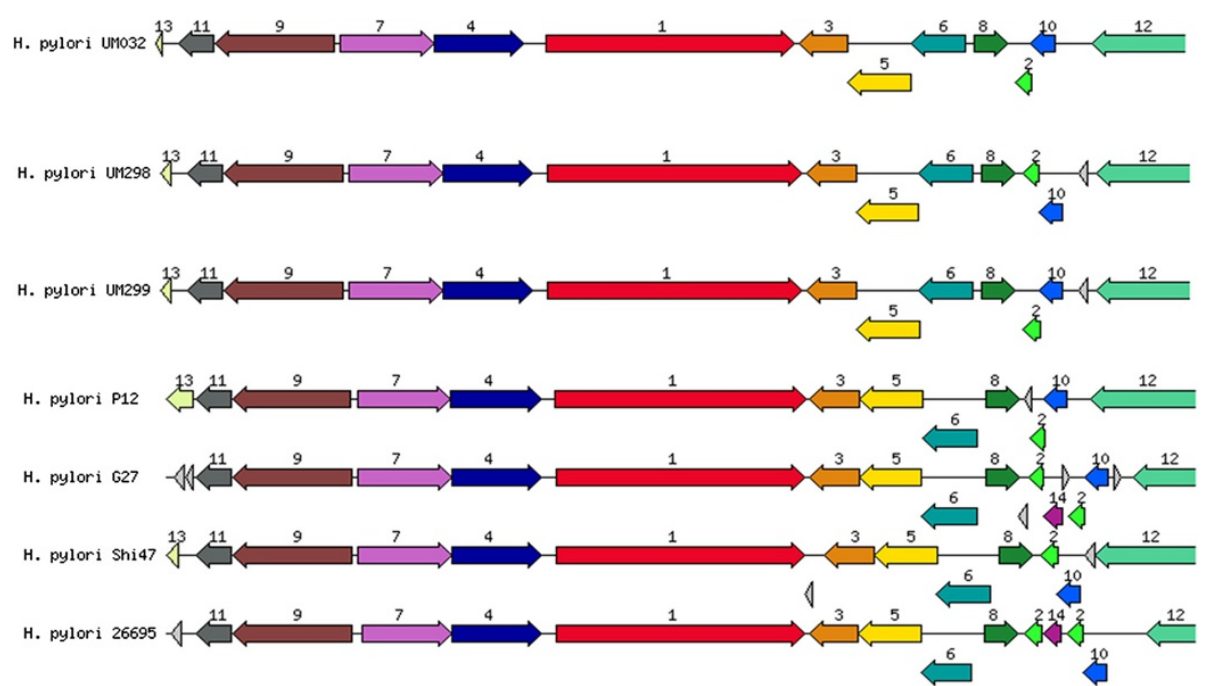

Figure 1 Genetic relatedness of vacA cluster with closely related bacteria. 1: vacuolating cytotoxin, 2: hypothetical protein, 3: haemin uptake system ATP-binding protein, 4: cysteinyl-Trna-SYNTHETASE, 5: IRON III, 6: dehydrogenases with different specificities, 7: proposted peptidoglycan lipid, 8: hypothetical protein, 9: hypothetical protein, 10: DNA damage inducible protein J, 11: holliday junction DNA helicase RUUA, 12: putative outer membrane protein, 13: hypothetical protein.

\footnotetext{
* Correspondence: jamuna@um.edu.my

'Department of Medical Microbiology, University of Malaya, Kuala Lumpur,

Malaysia

Full list of author information is available at the end of the article
}

\section{Ciomed Central}

(c) 2014 Khosravi et al.; licensee BioMed Central Ltd. This is an Open Access article distributed under the terms of the Creative Commons Attribution License (http://creativecommons.org/licenses/by/4.0), which permits unrestricted use, distribution, and reproduction in any medium, provided the original work is properly credited. The Creative Commons Public Domain Dedication waiver (http://creativecommons.org/publicdomain/zero/1.0/) applies to the data made available in this article, unless otherwise stated. 


\section{Author details}

'Department of Medical Microbiology, University of Malaya, Kuala Lumpur, Malaysia. ${ }^{2}$ Dental Research and Training Unit, Faculty of Dentistry, University of Malaya, Kuala Lumpur, Malaysia. ${ }^{3}$ Pacific Biosciences, Menlo Park, California, USA. ${ }^{4}$ PacBio Singapore, Singapore, Singapore. ${ }^{5}$ National Cancer Centre, Singapore, Singapore. ${ }^{6}$ School of Pathology and Laboratory Medicine, Faculty of Medicine, Dentistry and Health Sciences, University of Western Australia, Perth, Western Australia, Australia. ${ }^{7} T$ The Marshall Centre for Infectious Diseases Research and Training, University of Western Australia, Perth, Western Australia, Australia. ${ }^{8}$ Department of Medicine, University of Malaya, Kuala Lumpur, Malaysia. ${ }^{9}$ Department of Microbiology, Tumor and Cell Biology (MTC), Karolinska Institutet, Stockholm, Sweden. ${ }^{10}$ School of Biological Sciences, Nanyang Technological University, Singapore, Singapore.

Received: 28 April 2014 Accepted: 29 April 2014

Published: 8 May 2014

\section{Reference}

1. Khosravi Y, Rehvathy V, Wee WY, Wang S, Baybayan P, Singh S, Ashby M, Ong J, Amoyo AA, Wee SS, Choo SW, Perkins T, Chua EG, Tay A, Marshall BJ, Loke MF, Goh KL, Pettersson S, Vadivelu J: Comparing the genomes of Helicobacter pylori clinical strain UM032 and Mice-adapted derivatives. Gut Pathog 2013, 5:25.

doi:10.1186/1757-4749-6-11

Cite this article as: Khosravi et al:: Correction: Comparing the genomes of Helicobacter pylori clinical strain UM032 and mice-adapted derivatives. Gut Pathogens 2014 6:11.

\section{Submit your next manuscript to BioMed Central and take full advantage of:}

- Convenient online submission

- Thorough peer review

- No space constraints or color figure charges

- Immediate publication on acceptance

- Inclusion in PubMed, CAS, Scopus and Google Scholar

- Research which is freely available for redistribution

Submit your manuscript at www.biomedcentral.com/submit 